\title{
CONTEMPORARY CHALLENGES IN CHICANX/LATINX LITERATURE \& CULTURE
}

\author{
Francisco A. Lomelí, Sophia Emmanouilidou \& Juan Ignacio Oliva* \\ University of California Santa Barbara (USA), Aristotle University of Thessaloniki (Greece) \\ \& Universidad de La Laguna/GIECO-Franklin-UAH/Ratnakara
}

\begin{abstract}
This introductory paper traces a general perspective of the nowadays Chicanx/Latinx state of the question, including articles, notes, creative poems and drawings, and a tribute in memoriam Rudolfo A. Anaya (1937-2020). Challenging canons, norms and genres seems to be particularly appropriate when tackling ideology from the polychromatic gaze of transcultural minorities in the US. As such, Chicanx/Latinx literary and artistic expressions act as catalysts of renovation and change, not only in terms of content but also playing with forms in a freer, experimental way. Transgressing what is considered "normal" seems to be the only way to cope with fringes and frames, and thus a contemporary redefinition of the world is reached to highlight the "real" truth of artistic normativity.
\end{abstract}

Keywords: Chicanx/Latinx Literature \& Culture, Innovative Perspectives, State of the Question, Redefining Artistic Normativity.

\section{RETOS CONTEMPORÁNEOS EN LA LITERATURA \\ Y CULTURA CHICANA/LATINA}

\section{RESUMEN}

Este articulo introductorio ofrece una perspectiva general del estado de la cuestión actual, incluyendo ensayos largos, notas de lectura, poemas y dibujos, además de un tributo in memoriam Rudolfo A. Anaya (1937-2020). Parece propio de las minorías transculturales en los EE. UU. (que afrontan la ideología con una visión polícroma) el poner a prueba los cánones, las normas y los géneros. Así, las expresiones literarias y culturales chicanas/latinas sirven como catalizadoras de la renovación y el cambio, no solo en cuanto contenidos sino en su uso más libre y experimental de las formas. Transgredir lo que se considera "normal" parece la única manera de tratar con las estructuras encorsetadas, y de este modo redefinir el mundo que nos rodea para resaltar la "verdadera" realidad de la normatividad artística.

Palabras Clave: literatura y cultura chicana/latina, perspectivas innovadoras, estado de la cuestión, redefiniendo la normatividad artística.

DOI: https://doi.org/10.25145/j.recaesin.2020.81.02

Revista Canaria de Estudios Ingleses, 81; November 2020, pp. 13-24; ISSN: e-2530-8335 
Literary and artistic expressions by Chicanx and Latinx continue to make important inroads into realms of the American mainstream like never before. In fact, what was considered marginal or on the fringes by the academy nationally is oftentimes becoming a trailblazer of a new norm with new expectations as something groundbreaking within transnational circles. As useful as it is to deal with iconic authors from the United States, Chicanx/Latinx writers and other artists are chiseling away at the fortresses of standards and so-called artistic normativity. Readers/viewers across the world now pursue new voices who develop their craft in literature (a pan-Latinx phenomenon), art, film and other areas of creativity. Whereas aesthetic expression by Chicanx/Latinx used to be viewed as an anomaly, something outside the norm, we more and more find that they are pushing the envelope to challenge such antiquated notions of artistic normativity. This is why the different, the unorthodox, the unconventional, the untraditional have broken down glass ceilings and walls to occupy a reasonable place within the center of the canon, because this canon has become extended, expanded and redefined.

Precisely for these reasons, this special volume of the Revista Canaria de Estudios Ingleses checks the pulse of the most recent production via criticism to examine a wide array of works in different aesthetic forms. Thus, we offer a widespread collection of critical treatments on literary works by Chicanx and Latinx, but we also include innovative studies on art and film-which too often tend to be segregated as phenomena apart from the rest of the aesthetic world among Latinx. What we discover is that the critics from throughout the world here explore new avenues of discourse, theory, symbolism, technique, craft, language and ingenious approaches to render inventive treatments on works that otherwise might have remained undeveloped or understudied. $R C E I$, therefore, attempts to valiantly tackle such gaps while demonstrating unapologetically that criticism by international authors offers fresh views thanks to engagements with works that require a uniquely informed reader/viewer to decode what the creators are attempting to express. The authors and artists studied in this interdisciplinary volume truly present and offer nuances of new ground to discuss and analyze through a series of uniquely qualified prisms that most mainstream critics have not approached or tackled yet. This makes literary and artistic production by Chicanx and Latinx something with which to reckon as the world becomes an aleph, a twitter message, an Instagram, a blog or a nexus of new information within an instant.

Ever since the landmark work The Norton Anthology of Latino Literature (2011) appeared, it is becoming more difficult to keep calling writings by Chicanx and Latinx thinkers a minority literature. In fact, authors and artists are fast

* Juan Ignacio Oliva wishes to acknowledge the funds of the Research Project: "Estética, ética y estrategia de las nuevas cartografías migratorias e identidades transculturales en las literaturas en lengua inglesa del siglo xxı" "“Aesthetics, Ethics and Strategics of the New Migratory Cartographies and Transcultural Identities in Twenty-First-Century Literature(s) in English") [PID2019-109582GBIOO], granted by the Spanish Ministry of Science and Innovation. 
gaining readerships and audiences as they consistently inflect and transform the qualifications of aesthetic judgments. As a consequence, they are being recognized even among mainstream circles with prizes ranging from a US Poet Laureate (Juan Felipe Herrera) to PEN Awards, or from American Book Awards to many other stellar recognitions. So, this is not an isolated production, but rather, a new avenue in its own right that is becoming mainstream Americana (and international) like the salsa, guacamole, tacos and "Día de los Muertos."

The first section of the monograph consists of ten articles (plus and addendum) that offer contemporary approaches to Chicanx literary and cultural works of art. It opens with Amaia Ibarraran-Bigalondo's "Corridos," Tequila (and others), and Mexican/Chicano Masculinity," where she delves into "people's stuff" in a critical analysis that coalesces drinking tequila and the corrido tradition. Scrutinizing the song corpus of the corrido band Los Tigres del Norte, Ibarraran-Bigalondo tiptoes around varied significations connected with the consumption of alcohol, including masculinity, collectivization, belonging, borderland culture(s), and reciprocated or unrequited romantic relationships The article offers two comprehensive axes for the reading of drinking tequila: the compensatory and the celebratory. In the first axis, the use of alcohol is a solitary act, part and parcel of the "ethic model" of manhood, but it also becomes a way to compensate for emotional pain. Celebratory drinking, however, is performed as a collective act, a fiesta that reinforces some of the more "manly," or macho, characteristics of "lo mexicano/chicano."

On her side, M. ${ }^{a}$ Isabel Pérez Ramos looks into the conjoined issues of migration, labor exploitation, environmental degradation and toxicity in Lucha Corpi's novel Cactus Blood (1995). The author gives a close-up account of the migrant's vulnerability because of his/her exposure to social, political and environmental adversity. Pérez Ramos propounds that the migrant is conceived of as a "stranger," and as such becomes an identity in abeyance in the US-Mexico borderlands. The article departs from the critical interest in the Chicana feminist aesthetic(s) of Lucha Corpi's detective fiction. Instead, it discusses the novel from the socio-environmental and eco-cosmopolitan angles, which divulge the discriminatory policies of a global status-quo that turns people into "subaltern beings" for the growth rates of world agricultural production.

Giorgos Dimitriadis, accordingly, probes the multilayered, but also conjoined, uses of the Mexican celebration of the "Day of the Dead" (Dia de Muertos or Dia de los Muertos) in three film narratives: the surviving footage of ; Que Viva Mexico! (Sergei Eisenstein, 1931, unfinished), Coco (Lee Unkrich and Adrian Molina, 2017) and Spectre (Sam Mendes, 2015). Dimitriadis comments that although the three filmic representations of the "Day of the Dead" are markedly different from one another, all three films showcase a technical and thematic concern with liminality, or as the author phrases it, with the "in-between" quality of the specific cultural tradition. The article comprises three analytical sections, each focusing on a separate filmic event, but concludes with the in-depth argument that the crosscultural, transnational use of the tradition eludes the Mexican-specific paradigm of analysis. According to Dimitriadis, the "Day of the Dead" has transcended spatial and/or national identifiers, thus stretching its signification to the larger public. And 
in this light, he adds that the "Day of the Dead" immerses viewers to a cultural resemanticizing of spatio-temporal confines, folklore and aesthetics.

Next article, by Aikaterini Delikonstantinidou, discusses two Chicana/o revisions of the tragic myth of Oedipus in conjunction with recent studies of the American prison crisis. The author argues that Luis Alfaro's "Oedipus el Rey" (2010) and Law Chavez's "Señora de la Pinta" (2012) are plays that largely intertext with Sophocles' Oedipus Tyrannus. Delikonstantinidou bears upon Ernest Drucker's notion of the "plague of prisons" to further explore the repercussions of mass incarceration on barrio family, communal life and, eventually, Chicana/o social standing in the US. The article maintains that the imprisonment of Chicana/o youth is not the outcome of a current social crisis, but the transmutation of an age-old tale of victimization: a tale that sheds light on the tragic fate of a corpus pintao, a fate inscribed on poor communities of color upon birth. Ultimately, Delikonstantidou pinpoints the quasi-didactic quality of "Oedipus el Rey" and "Señora de la Pinta" with the critical statement that in their distinct attempts at dismantling the pipeline, both plays summon communities to facilitate the reintegration of pintos into barrio life, thus eluding the dual perils of recidivism and incarceration.

Sebastián Imoberdorf, a new $\mathrm{PhD}$ in Latin American and US Latino literatures and cultures from the University of Fribourg, Switzerland, offers an insightful display of the relationship between official documents (i.e. "Universal Declaration of Human Rights") and literary works by two male and one female writers, who capture intimate connections to Latin America and the US. He discusses in considerable depth the vulnerabilities and issues that certain marginal characters experience. Specifically, he focuses on illegal or undocumented persons to which he refers to as "irregular" status, homosexual individuals (in this case from Cuba), and women who suffer one kind of abuse or another. Together, the three examples confront violence in various forms: physical, sexual and psychological. The works he uses to exemplify such situations are as follows: El corrido de Dante by Eduardo González Viaña (dealing with immigrant issues); Antes que anochezca by Reinaldo Arenas (concentrating on homosexuals), and El sueño de América by Esmeralda Santiago (emphasizing violence toward women). The study makes strong cases for couching their thematics within the legal and moral purviews of human rights.

Film is another area that fortunately is included in this volume, thanks to David R. Maciel who presents an extensive study titled "Vision of Aztlán: The Chicano Documentary Film," a topic inexplicably but rarely studied in depth. As a Professor Emeritus from California State University at Dominguez Hills and an Associate Professor at the Centro de Investigación y Docencias Económicas in Mexico City, he presents an exemplary overview of Chicano documentary film from its inception during the Chicano Movement (1965-1980) to current times, thereby providing critical vistas of some of the salient works, their characteristics and contributions. Complementing a meticulous examination of each documentary, the author also gives extensive historical background along with enlightening commentary on the directors themselves and the trailblazing efforts on their behalf. As a result, the reader can also find considerable discussion of a variety of cultural entities that supported such a filmic enterprise and the difficulties involved producing 
documentaries by both Chicanos and Chicanas, but also by other directors who saw the merit of documenting certain life experiences related to this ethnic community.

Another important topic that is central to Chicanx literature overall is the focus on Chicanas or Latinas as writers, particularly in fiction. Monica Got, a lecturer at Bucharest University of Economic Studies, precisely explores this topic in great detail in her study titled "Toward a Geography of Trauma: From El Plan Espiritual de Aztlan to the Birth of Chicana Spiritual Feminism.” Based on careful examinations of various authors in relation to a nuanced theoretical apparatus, the critic presents a robust discussion and analysis on how Chicanas overcame their social-cultural predicaments within the Chicano Movement, which proved to be strongly male-oriented. The barriers ceased to be only symbolic but actually became very real, so Chicanas experienced a rebirth of their own, while at the same time they created a literary movement within a movement beginning in the early 1980s. First of all, they had to confront, escape and challenge their own community's deeprooted or entrenched sexism, racism and homophobia. The author here provides the background and context under which Chicana literature took on its own particular characteristics and features, thanks in part to such pioneers as Gloria E. Anzaldúa, considered the foremother of their feminism, particularly in Borderlands/La Frontera: A New Mestiza (1987). Therefore, the contrast between a male-dominated movement and a Chicana-centric literary production generated a new aesthetic and a long list of writers who are integral to the field of Chicanx literature. By concentrating on the geography of trauma, we are informed of the key roles by such writers as Sandra Cisneros, Ana Castillo, Cherríe Moraga, Emma Pérez, and others who have created a feminist discourse of resistance.

In another study, "Hermeneutic Distanciations in Postmodern Chicanx Literature: Utopian and Dystopian Horizons in Ana Castillo's So Far from God (1993) and Salvador Plascencia's The People of Paper (2005)" by Michael Grafals from Florida International University, the author proposes a fascinating read of two key postmodern novels from Chicanx literature. Heavily based on concepts and ideas by theoreticians Hans-Georg Gadamer, Paul Ricoeur, Stuart Hall, Emma Pérez and others, we are able to determine how such works emerge from larger social-cultural backgrounds that are intimately couched within postmodern aesthetics. Part of the argument is that Chicanx works are no longer isolated literary productions that would otherwise be deemed provincial or limited in scope. The critic outlines with compelling evidence that such works can be viewed as having ties with Ricoeur's concept of "distanciation" (related to estrangement), Gadamer's "hermeneutic phenomenology," Pérez's "decolonial imaginary," and Stuart's "conception of articulation"-all within the theoretical impulses of postmodernism. The original readings of So Far from God and The People of Paper will forever change and tilt the way we approach these novels, opening up new ground for critical consideration.

Allison Ramay from the Pontificia Universidad Católica de Chile presents "Radical Hope in Cherríe Moraga's The Hungry Woman: A Mexican Medea" in which she studies a foundational writer who engages in recreating a Greek myth, in this case a Mexican Medea. By focusing on such a myth, the author is able to unravel the contents of a radical hope as it pertains to how some Chicanas not only 
reevaluate key female figures, but also how they actually propose a radical critique of patriarchy, heteronormative and other macho social constructions. What emerges is a clear concept of "Queer Aztlán," as often propagated by Cherríe Moraga in this work and others. A detailed recreation of Medea helps us reevaluate how patriarchy and feminism can coexist while the symbolism of the protagonist within a Mexican/ Chicano cultural setting is valued in terms of deconstructing modern machismo. The use of myth, in this case a strongly feminist archetype, opens up new theoretical possibilities to understand the past and prepare for the future. It would appear that only a radical hope can accomplish this.

Finally, in "The Coatlicue's State in The Mixquiahuala Letters: A Postmodern Interpretation of How to Reach the Mestiza Consciousness," Mariela Aguilar outlines a clear and extended analysis-both theoretical and textual-of Ana Castillo's The Mixquiahuala Letters in relation to some of the key tenets of Gloria E. Anzaldúa, who produced a watershed landmark in 1987 with Borderlands/La Frontera: The New Mestiza. The study marks a significant contribution toward decoding central aspects of Castillos' novel which too often has been glossed over by critics by effectively discussing its genesis, its inspiration and its strategies for reading it. Consequently, we come away with a deeper sense of unraveling the novelistic apparatus used to develop technique, point of view and ideology of the narrator, all couched within postmodernism and a revitalized feminism. The result is a more critically holistic approach toward understanding the many complexities of the novel's context and the warning signs the Chicano Movement was unable to see at the time of The Mixquiahuala Letters' publication in 1985.

The "Articles" section closes with an interesting addendum to the study of Chicanx/Latinx literary and cultural corpora. Carolina Fernández Rodríguez, in "Helen Hunt Jackson's Ramona: The Romance that Became a Tourist Guide and Silenced the Mestiza," peeps into the subjective, often dismissive, portrayal of Latinx in the late $19^{\text {th }}$ century, tracing a detailed research of historical and narrative value. As it is well known, José Martí (1853-1895), the leader and spokesman for Cuba's revolution of independence against Spain, spent a great part of his adulthood in exile in New York City. In October of 1885 he attended a conference on Indian affairs at Lake Mohonk in upstate New York. There he learnt about Helen Hunt Jackson, who had recently passed away, and about her novel Ramona (1884), which she had intended as a piece of activism on behalf of the Indigenous peoples of California. Martí was so struck by Jackson's novel that he decided to translate it into Spanish and to publish it at his own expense. His translation came out in 1888. In the introduction, he stated: "Few books are of greater interest than Ramona, and few leave the reader with so sweet an impression" (357).

Ever since then, many Hispanics have felt compelled to read Jackson's romance story between Ramona-a mestiza, and Alessandro-a Native-set in California in the days after the Mexican American War. In the introduction to the 2005 edition of Jackson's novel, Chicana writer Denise Chávez recounts her first reading of Ramona, when she was in her fifties. Unlike other friends of hers who had read the novel as teenagers, and were therefore infatuated with the romantic elements in the story, she approached the text as a knowledgeable adult: "I was inculcated 
with the fantasy of the American West, you White, you Injun, me Mexican-make that a wetback. I knew my place" (xiii). Because Chávez was a critical reader, she was soon appalled by the stereotypical portrayal of Indigenous characters and those of Mexican descent. Only a few pages into the novel, she saw it not as an example of social advocacy, as its author had intended it to be, but of $19^{\text {th }}$-century Anglo views on people of other ethnic backgrounds: a "legacy of untruths," as she puts it (xv). Chávez went on reading, nonetheless, compelled to do so by the lyrical beauty of the descriptions of the landscapes of California before the arrival of estate development and agribusiness, and also because at times she identified with the novel's heroine and her strength in adversity. In any case, Chávez admits that reading Ramona from the point of view of a $20^{\text {th }}$-century Chicana was "a deeply disturbing journey" (xix), and yet, one from which present-day Americans could learn a poignant lesson: "Little has changed" (xix).

Indeed, today, just as in the $19^{\text {th }}$ century, many people of minority ethnic backgrounds, Indigenous and Latinx, keep losing their mother languages; the land that was taken from them is forever gone, and now they are running out of water, too; racism and denigration still exist; immigration policies continue to cause immense pain, even the deaths of hundreds of people as they cross the border; racial violence keeps triggering mental issues, exactly the way it did to Alessandro. In short, all the problems denounced by Jackson's novel remain virtually unchanged, or worse, increased. In Chávez's opinion, that Ramona portrays not only the struggles of $19^{\text {th }}$-century minoritized peoples, but also those of present-day Latinx justifies that we continue to read Jackson's romance and to learn from it. Chávez suggests that we ask ourselves: "Who does the land belong to and who belongs to the land?" (xxi), and also: "What matters to us, as a nation and a people who are of the people, for the people, and by the people? And just exactly who would those people be?" (xxi). In other words, Chávez argues that Ramona, despite its shortcomings, can still help Americans ponder on issues related to the question of national identity, that is, who belongs in the country's collective imaginary as American. Even more importantly, Chávez claims that Jackson's novel can impel contemporary readers to consider the extent to which American democratic principles, as stated in the country's Constitution, still fail to apply to certain Americans on account of their ethnicity. Thus Ramona speaks to us and invites us to see the plight of many presentday Latinx in the context of a long history of discrimination and usurpation.

This issue of Revista Canaria de Estudios Ingleses includes as well a special "Notes" section, devoted to young scholars, featuring four contributions by postgraduate students enrolled in the Master's Degree in English and American Studies at the School of English, Aristotle University of Thessaloniki, Greece. Foteini Toliou's article looks into the transhistorical subordination indigenous and mestiza/o identities were/have been/will be subjected to in the borderlands between Mexico and the US. In her reading of Alejandro Morales's novel, The Rag Doll Plagues (1992), Toliou examines a tripartite strategy of control and/or suppression in the borderlands: Spanish colonialism, US racism and eco-destruction, each strategy transpiring in different moments of 'New World' history. The sociopolitical and cultural dominations that Toliou analyzes illustrate diverse expressions of a 
borderland crisis in the three Books that comprise Morales's novel. The article concludes with an insightful comment that in The Rag Doll Plagues, Morales sustains the belief that mestizaje, intercultural communication and the reclamation of the indigenous and Mexican cultural traditions, like curanderismo, can arise as the analeptics to the plight of racial discrimination. Stylianos Papadimitriou zooms on Gregory Nava's film narrative My Family (1995) in a critical analysis that investigates the development of Chicana/o identity in the American Southwest. The article offers a close reading of a Mexican and/or Chicana/o family's spatial peregrinations, cultural negotiations and personal struggles amidst a wide array of changing and often perilous social realities. The parents of the family enact the hesitations of the first-generation Mexican immigrant to embrace the American lifestyle. In fact, the parents' identity profile showcases a close adherence to their Mexican roots, while their children, having been raised in the US, challenge the traditions and norms they have inherited from them. Papadimitriou adds that most of the children in $M y$ Family question and defy mandates of being-in-the-world, thus crafting the novel identity of a contemporary Chicana/o, an identity that is molded by layered sociocultural conflicts.

Maria Ntokli examines Ana Castillo's use(s) of the archetype of La Malinche, the woman who has embodied the role of the female traitor in Latin American history and folklore. The article attempts a nuanced approach to Castillo's feminist perspective in her epistolary novel The Mixquiahuala Letters with the central critical comment being that the author draws from La Malinche in the creation of her Chicana protagonist, narrator and letter-writer. Ntokli purports that Teresa is a reinvention of La Malinche, a character who is faced with multiple difficulties north and south of the border: gender suppression, violence, emotional depravity, the commodification of her skin color/body, the challenges of being a cultural mediator, and so on. Ntokli claims that in order to subvert the derogatory connotations associated with 'brown' women, The Mixquiahuala Letters unravels the sexist double standards both La Malinche and Tereza have had to endure. Channeled through historical and cultural narratives of sexism, narratives perpetrated by Europeans, Indians, Mexicans and Chicanos alike, sexist agendas dominate and hinder both La Malinche's and Tereza's efforts to attain historical truth, emancipation and personal bliss. The article concludes with an insightful coalescence of las tres madres ( $\mathrm{La}$ Malinche, La Llorona and La Virgen de Guadalupe) in Tereza's character arch and suggests that Castillo delves into Tereza's experience so as to propose a Xicanista vision, a vision that urges our understanding of the past in order to be able to craft a more equitable future. Anastasia Miskaki departs from the usual feminist angle with her critical venture into an ecofeminist reading of Sandra Cisneros's "Eyes of Zapata." The article holds that Inés, one of Emiliano Zapata's mistresses and the narrator of the novella, embodies the strange and/or formidable Other in traditional, androcentric communities. Miskaki underlines the parallel structures between Inés and the physical cosmos: both have been silenced, perceived as threatening, used and abused in humanity's histories. The article claims that Inés is sketched out as a curanderalbruja, character traits that allow Inés to develop a spiritual relationship with nature. Through her broodings and visions, but also her immersion in the 
practices of curanderismo and brujeria, the female narrator achieves an accord with the natural environment, a harmonious union that alleviates the pain caused by abandonment, rejection and betrayal. Apart from the analogies between Inés and nature, Miskaki elaborates on the contrasts between Inés and Emiliano Zapata, her lover and the father of her two out-of-wedlock children. Zapata's domineering and imperious approach to the elements of nature is strikingly different from Inés's nature-inspired actions and survival tactics. Finally, the article claims that despite patriarchy's and machismo's attempts to weaken and/or efface her, Inés prevails as a potent female character, one who empathizes with the physical cosmos and, by extension, voices the historical experiences of silenced women.

The "Creation" section that closes the monograph includes a preliminary piece by Francisco A. Lomelí, in which a moving and most necessary tribute is payed to the recently passed away founding father of the contemporary chicanx narrative: Rudolfo A. Anaya (Oct 1937-June 2020). After the sensible discourse of the distinguished scholar devoted to the reputed author and friend, a short and personal biography is also included. Furthermore, we are very fortunate to offer a variegated list of authors from various generations as examples of current poetic production among Chicanx and Latinx in the US. We immediately discover that the approaches, thematics, techniques and forms utilized vary drastically: from the lyrical to the personalized chronicle, from the political to the meditative, from an emphasis on image to the petite histoire, from the evocative to experimental, or from the haiku to the prosaic reflection. We also recruited well-established writers and upcoming ones, again, to provide a representative cross-section of the kind of voices and topics that concern these poets. Juan Felipe Herrera as the first Chicano US. Poet Laureate leads the list followed by the iconic Alurista, who has had the most extensive career of our contributors. In addition, we also have scholar-poets such as María Herrera-Sobek, Alejandro Morales and Gustavo Segade (also an artist) who share with us deeply personal reflections about their lives. Plus, Thelma Reyna and Luivette Resto are experienced writers of poetry who enhance the thematics in this section of poetry, accompanied by Juan Casillas Núnez whose participation is more well known for his book on Estela Portillo Trambley, offering us a unique view of current political discourse in the United States.

Among the contributors to this poetry section are:

Juan Felipe Herrera, the first Chicano to have been appointed as US. Poet Laureate in 2015 and 2016, here offers glimpses into new waves of poems and styles as he continues to experiment with form and language. He has an extensive career of over 20 books, mainly poetry but also some novels, including novels for young adults and children's literature. He is currently the most anthologized and coveted Chicano poet after having garnered many literary awards. Among some of his most well-known books are Akrilica (1989), Cinnamon Girl: Letters Found Inside a Cereal Box (2005), many others and most recently Every Day We Get More Illegal (2020) and Borderbus (2020). Alurista here contributes hikus from his most recent book $Z A Z$, which is about to be published in 2020 . He returns to a poetic genre he developed extensively in the 1970s and 1980s, while combining some with glyphs and highly experimental imagistic poetry in Spanglish. Most of us know 
him as the principal and most transformative poet of the Chicano Movement for his creativity, his teaching and his fight for social justice. Among his most classic works are Floricanto en Aztlán (1971), Spik in Glyph? 1981), As Our Barrio Turns... Who the Yoke B On? (2002), among others. Gustavo Segade of Puerto Rican and Cuban background was instrumental in the founding of the Mexican-American Department at San Diego State University in 1969. He initiated his career as a critic of Latin American poetry and has since indulged in drawing and painting highly original sketches (often of five faces or five people) in very unique color schemes. His poetry is indeed contemporary in dealing with the coronavirus and issues of coming to terms with his sons' sexuality.

Thelma T. Reyna, moreover, offers personal glimpses into her formation as a woman and poet. Her books have collectively won 16 national literary awards, having written 6 books, and edited 3 anthologies. Her most recent book is Dearest Papa: A Memoir in Poems (2020). Her fiction, poetry, and nonfiction have appeared in literary journals, anthologies, textbooks, blogs, and regional media for over 25 years. She was a Pushcart Prize Nominee in Poetry in 2017. She received her Ph.D. at UCLA and was named the Poet Laureate for Altadena, California for 2014-2015. Alejandro D. Morales has a well-chronicled career in fiction writing, having produced a series of landmark novels that are considered must-reads in the US and abroad. His originality in terms of thematics and subject matter are unmatched, but here he offers one poem that is intimately related to a Spanish subject. We can see his poetic prowess, which is thought to be somewhat obscured by his novels and short stories. Clearly we view another important facet of this diverse author. He is about to publish his first book of poetry, titled Zapote Tree (in press; 2020). Luivette Resto, a mother, teacher, poet, and Wonder Woman fanatic, was born in Aguas Buenas, Puerto Rico, but proudly raised in The Bronx. Her two books of poetry Unfinished Portrait and Ascension have been published by Tía Chucha Press. Her latest poetry collection Promises Are Coffee is forthcoming by FlowerSong Press. She lives in the Los Angeles, California area. María Herrera-Sobek is a world-class critic of Chicanx literature who has exhibited superb ambassadorial skills by promoting Chicanx literature throughout the world, including Latin America, much of Europe, the Middle East and even Siberia, Russia. She has published numerous poems from a feminist perspective (in a collection titled Three Times a Woman: Chicana Poetry (1989) along with Alicia Gaspar de Alba and Demetria Martínez) turning now to a more personal, almost existential view of the world. And last but not least, Juan José Casillas-Núñez has published various short stories, his genre of predilection, in various literary journals in the US and Spain. His specialization is teaching the Spanish language to students with a focus on heritage speakers. However, his innovative poem-calligram touches a sensitive nerve of what is occurring in the United States at the social and political level, showing that politics is sometimes inevitable. He has published a critical study titled Estrategias filosóficas y discursivas de Estela Portillo Trambley (2017).

To sum up, this issue offers the outcome of a transcontinental, transnational and interdisciplinary collaboration, a border crossing of critical thinking. Naturally, compiling the articles that appear in this volume required the combined skills of 
negotiation, receptiveness and courtesy. Given that distinguished and young scholars from Europe and the United States conferred and also joined their distinct theoretical perspectives and academic backgrounds in the production of this collection of articles, it is our sincere hope that the dynamics of Chicanx Culture will be further explored in this vein. Pondering on Francisco A. Lomelís critical proposition, "[w] hat matters most is to measure what is being produced, what is occurring, and how it opens new grounds for experiential knowledge or vicarious enlightenment within an interdisciplinary focus of multicolored components" (221). So let us conclude with a familiar motto: "With discipline we perform, with difference we thrive!"

REVIEWS SENT TO AUTHOR: 11-7-2020; REVISED PAPER ACCEPTED FOR PUBLICATION: 15-9-2020 


\section{WORKS CITED}

Chávez, Denise. "Intoduction. My Long Hot Ramona Summer." Ramona. The Modern Library, 2005. xiii-xxii.

JaCKson, Helen Hunt. Ramona. The Modern Library, 2005 [1884].

Lomelí, Francisco A. "The Chicano Reinvention of America: Is Cultural Essentialism Dead? Or, Breaking the Gridlock on Poetics of Indifference." Ecrire la Difference: Interculturalism and the Writing of Difference. Ed. Jean Beranger et al. Editions de la Maison des Sciences de l'Homme d'Aquitaine, 1993. 211-22.

Martí, José 1887. "Introduction to the 1888 Spanish Edition of Helen Hunt Jackson's Ramona." Transl. \& publ. José Martí. English transl. Esther Allen. Ramona. The Modern Library, 2005[1887]. 357-359.

Stavans, Ilán, et al., eds. The Norton Anthology of Latino Literature, W.W. Norton \& Company, 2011. 